\title{
WACANA KESETARAAN GENDER DALAM MEME HADIS: STUDI ETNOGRAFI VIRTUAL PADA AKUN INSTAGRAM @MUBADALAH.ID
}

\author{
Kholila Mukaromah \\ IAIN Kediri \\ kholilamukaromah@iainkediri.ac.id
}

\begin{abstract}
This article examines the discourse of gender equality in hadith memes as expressed in the instagram posts of the @ mubadalah.id. It questions the form of hadith memes that contain the Islamic messages of gender equality and the motives behind it. This research employs virtual ethnographic method and descriptivequalitative analysis. This study suggests that, in general, the forms of gender equality discourse carried out by the @mubadalah.id aimed at strengthening the recognition of women's existence in the domestic, public, and religious affairs. This article classifies several memes of hadith into three major themes: first, a counter to the stigmatization of women as a source of slander and having lack of reason and religion; second, the concept of mahram for women; and third, women in the vortex of polygamous marriage. There are at least two motives behind the posts of hadīth memes in the @mubadalah.id: first, hadìth memes as a response to the current phenomenon; second, hadith memes as a medium of socialization and publication of mubädalab ideas.
\end{abstract}

Keywords: Hadīth memes; mubadalah.id; gender equality; virtual ethnographic.

Abstrak: Tulisan ini mengkaji tentang wacana kesetaraan gender dalam meme hadis yang akan difokuskan pada postingan akun instagram mubadalah.id. Beberapa pertanyaan yang diajukan terkait dengan apa saja bentuk meme hadis yang diunggah oleh akun @ mubadalah.id yang memuat pesan kesetaraan gender dalam Islam serta motif apa saja yang melatarbelakangi unggahan meme hadis tersebut. Penelitian ini dilakukan dengan menggunakan metode etnografi virtual dan dianalisis secara deskriptif-kualitatif. Hasil penelitian menyebutkan bahwa secara umum bentuk-bentuk wacana kesetaraan gender yang diusung oleh akun @mubadalah.id terfokus pada pengakuan dan eksistensi perempuan baik di ranah domestik 
maupun publik, bahkan dalam ranah keagamaan. Peneliti dalam hal ini melakukan studi kasus atas beberapa meme yang diklasifikasikan ke dalam tiga tema besar, yakni: pertama, counter atas stigmatisasi perempuan sebagai sumber fitnah, serta kurang akal dan agama; kedua, konsep mahram bagi perempuan; dan ketiga, perempuan dalam pusaran pernikahan poligami. Setidaknya ada dua motif yang melatarbelakangi unggahan meme hadis dalam akun@mubadalah.id. pertama, meme hadis sebagai respon atas fenomena kekinian; kedua, meme hadis sebagai media sosialiasi dan publikasi gagasan mubadalah.

Kata Kunci: Meme hadis; mubadalah.id; kesetaraan gender; etnografi virtual.

\section{Pendahuluan}

Pro-kontra atas wacana kesetaraan gender telah lama terjadi di kalangan umat Islam. Perbedaan pandangan ini pada dasarnya berangkat dari pola pemahaman yang berbeda dalam menafsirkan teks-teks al-Qur'an maupun Hadis. Kubu yang menolak wacana ini biasanya menggunakan cara pandang literalis dalam memahami petunjuk yang disampaikan ayat-ayat al-Qur'an maupun Hadis. Sebaliknya, kelompok yang menyuarakan wacana ini memahami petunjuk teks-teks agama secara lebih kontekstual dengan mempertimbangkan latar belakang sosio-historis serta mengkonfirmasikannya dengan teks-teks lain dengan pendekatan keilmuan interdisipliner bahkan multidisipliner.

Diskursus mengenai hal ini semakin meluas di era berkembangnya teknologi informasi dan digital. Jika sebelumnya perdebatan kesetaraan gender lebih banyak muncul di kalangan para pakar, praktisi, maupun akademisi, maka di era digital, khususnya dengan kehadiran media social, khalayak yang memperbincangkannya datang dari berbagai latar belakang dan struktur sosial. Wacana mengenai hal ini pun dikemas dalam berbagai bentuk yang lebih menarik dan mudah diterima oleh pembaca. Salah satu bentuk media yang digunakan untuk menyebarkan informasi mengenai hal ini yaitu meme yang banyak diunggah di laman media sosial, baik facebook, whatsapp, instagram, dan lain sebagainya.

Pro-kontra poligami misalnya, peneliti menemukan adanya meme yang mengusung wacana pro dengan mengutip terjemahan hadis riwayat Bukhari nomor 4681 berikut: "Menikahlah, karena orang yang 
terbaik dari ummat ini adalab orang yang paling banyak wanitanya". Sebaliknya, meme lain menyiratkan kontra terhadap praktik ini seperti halnya dalam beberapa meme akun@mubadalah.id yang menyatakan bahwa dalil hadis tentang kebolehan poligami palsu, dan juga terdapat meme yang mengutip hadis Bukhari nomor 5285, bahwa Nabi Muhammad tidak rela jika Fatimah dipoligami. ${ }^{3}$

Munculnya hadis-hadis dalam meme tersebut menjadi kajian yang menarik untuk diamati. Jika sebelumnya kajian hadis terkesan eksklusif hanya dikaji di kalangan pesantren, pengajian, diskusi kajian keislaman, serta perguruan tinggi saja, maka di era berkembangnya interaksi di media sosial hadis menjadi 'hidangan' bagi semua kalangan. Penyajian hadis dalam bentuk meme juga semakin menarik manakala teks hadis disandingkan dengan gambar visual yang mendukung makna dari teks hadis tersebut. Salah satu yang menarik adalah apa yang dilakukan oleh akun@mubadalah.id di instagram. Melalui akun tersebut, meme hadis dengan beragam tema yang sebagian besar menyiratkan ideologi kesetaraan perempuan sering diunggah.

Tulisan ini selanjutnya akan mengelaborasi secara deskriptifanalitis sejumlah meme hadis yang diunggah dalam akun @ mubadalah.id. Sejumlah pertanyaan yang akan diajukan yakni apa saja bentuk meme hadis yang diunggah oleh akun@mubadalah.id yang memuat pesan kesetaraan gender dalam Islam? Serta bagaimana motif yang melatarbelakangi unggahan meme hadis tersebut? Penelitian dilakukan dengan menggunakan metode etnografi virtual ${ }^{4}$ dengan paradigma konstruktivisme.

\footnotetext{
${ }^{1}$ Meme dari akun instagram fahd_hasan24, "Silahkan tinggalkan poligami bagi yang tak mampu, silahkan berlaku adil bagi yang bisa," Instagram, 1 Juni 2019, diakses 11 Agustus, 019, https:/ /www.instagram.com/p/ByJ5gxqnjmt/igshid=1kr0yp5rrdzca. 2 Mubaadalah, "Hadis Palsu Poligami," Instagram 14 Juni 2019, diakses 12 Agustus 2019, https://www.instagram.com/p/ByrnikWAA-J/.

3 Mubaadalah, "Nabi Saw 'tidak rela' Fatimah (Putri Baginda) Dipoligami", Instagram, 15 Juni 2019, diakses 12 Agustus 2019, https://www.instagram.com/p/ByuvwkJAAhw/.

${ }^{4}$ Etnografi virtual merupakan salah satu varian dari metode etnografi secara umum. Hanya saja etnografi virtual wilayah kajiannya lebih sempit, yakni hanya mencakup realitas di dunia maya. Sehingga etnografi virtual bisa dipahami sebagai metode etnografi yang dilakukan untuk melihat lebih jauh tentang bagaimana fenomena sosial - budaya terjadi dalam ruang virtual. Rulli Nasrullah, Teori dan Riset Media Siber (Cybermedia) (Jakarta: Prenadamedia, 2014), 13. Istilah lain yang terkait yaitu:
} 
Penelitian mengenai meme sebenarnya telah banyak dilakukan. Seperti halnya "Fenomena Meme di Media Sosial: Studi Etnografi Virtual Posting Meme Pada Pengguna Media Sosial Instagram" telah ditulis oleh Aditya Nugraha"; "Pesan Ramah dalam Akun Instagram Jaringan Gusdurian dan Fihril (Kajian Pragmatik) ditulis oleh Rifatul Mahmudah dan Imron Gozali. ${ }^{6}$ Akan tetapi yang mengkaji secara khusus meme hadis bisa dikatakan masih sedikit. Hal ini seperti yang dilakukan oleh Miski dengan artikelnya berjudul "Fenomena Meme Hadis Celana Cingkrang dalam Media Sosial"; ' dan Syahridawati dan Saifuddin Zuhri dalam artikelnya yang berjudul "Contestation of Hadith Memes on the Prohibition of Music." ${ }^{8}$ Sedangkan penelitian yang meneliti akun@mubadalah secara khusus baru dilakukan oleh Aurora Nurhidayah R. dalam tesisnya yang berjudul "Media Sosial dan Aktivisme: Medium Pemaknaan Ulang Narasi Islam oleh Akun Instagram@mubadalah.id,@muslimahfeminis, dan @ cherbonfeminist." Berdasarkan hasil telaah pustaka yang telah dijabarkan sebelumnya, kajian mengenai meme hadis yang bermuatan wacana kesetaraan gender di media sosial belumlah banyak dilakukan.

Penelitian ini dapat menjadi titik permulaan yang mengintegrasikan kajian teks-teks hadis dengan kajian media baru (new media) yang dirasa masih sangat minim. Dalam kacamata living hadis sendiri, peneliti melihat bahwa meme hadis tersebut merupakan upaya menghidupkan hadis atau sunnah (ihy $\vec{a}$ ' al-sunnah) yang memiliki nuansa kesetaraan gender dalam ruang digital yang sangat akrab dengan dunia generasi milenial.

netnography, webnography, netwotk ethnography. Bayu Indra Pratama, Etnografi Dunia Maya Internet (Malang: UB Press, 2017),102.

${ }^{5}$ Aditya Nugraha, "Fenomena Meme di Media Sosial: Studi Etnografi Virtual Posting Meme Pada Pengguna Media Sosial Instagram," Jurnal Sosioteknologi, Vol. 14, No. 3 (2015).

6 Rifatul Mahmudah dan Imron Gozali, "Pesan Ramah dalam Meme Akun Instagram Jaringan Gusdurian dan Fihril ( Kajian Pragmatik)," Jurnal Estetik, Vol. 1 No. 2 (2018), 117-134.

${ }^{7}$ Miski, "Fenomena "Meme" Hadis Celana Cingkrang Dalam Media Sosial", Jurnal Harmoni: Jurnal Multikultural dan Multireligius, Vol. 16, No. 2 (2017), 291-305.

8 Syahridawati dan Saifuddin Zuhri, "Contestation of Hadith Memes on the Prohibition of Music", Journal of Hadith Studies, Vol. 2, No. 1 (2019).

99 Aurora Nurhidayah Rifani, "Media Sosial dan Aktivisme: Medium Pemaknaan Ulang Narasi Islam oleh Akun Instagram @mubadalah.id, @muslimahfeminis, dan @ cherbonfeminist", Tesis, Universitas Indonesia, 2020. 


\section{Sekilas Mengenai Akun Instagram@Mubadalah.id}

Akun Instagram@mubadalah.id mendeskripsikan dirinya sebagai portal Islam dan relasi yang membahagiakan. Selain aktif di instagram, mubadalah.id juga aktif di platform media sosial lain, di antaranya: Mubadalah.id (facebook); @mubaadalah_id (twitter); Mubadalah Id (youtube); dan mubadalah.id (versi website). Akun ini dibuat sejak tahun 2016 dan terhitung hingga 19 September 2020 telah mengunggah 703 kiriman di laman akun instagramnya. Akun ini telah diikuti oleh 19.900 pengikut (followers) dan juga hanya mengikuti 163 akun instagram lain (following).

Berdasarkan hasil wawancara, diketahui bahwa pada mulanya akun ini dibuat oleh Bang Dul, Bang Ocid, dan Bang Aril. Meskipun gagasan mubadalah dicetuskan oleh Faqihuddin Abdul Kodir, akan tetapi soal publikasi gagasan tersebut di media sosial lebih banyak ditangani mandiri oleh para redakturnya. ${ }^{10}$ Penamaan akun dengan (a) mubadalah.id tidak terlepas dari peran Faqihuddin Abdul Kadir. Ia bisa dikatakan sebagai founder atau pencetus konsep mubädalah yang kemudian berusaha disosialisasikan secara lebih luas dengan memperkenalkannya di berbagai media sosial. Faqihuddin sendiri kemudian menuliskan idenya tentang konsep mubädalah tersebut dalam karya besarnya, Qiräah Mubādalah: Tafsir Progresif Untuk. Keadilan Gender dalam Islam. Oleh karenanya, filosofi dari nama akun @mubadalah.id bisa dikatakan tidak terlepas dari gagasan Faqihuddin dalam karyanya tersebut.

Istilah mubādalah berasal dari bahasa Arab مُبَادَلَّة. Kata ini berasal dari akar suku kata "ba-da-la" (J - د - ب) yang berarti mengganti, mengubah, dan menukar. Akar kata ini muncul di al-Qur'an sebanyak 44 kali dalam berbagai derivasi dan maknanya. Sementara bentuk kata "mubädalab" sendiri mengandung makna kesalingan (mufäalah) dan kerjasama antara dua pihak (mushärakah) yang berarti saling mengganti, saling mengubah, atau saling menukar satu sama lain. ${ }^{11}$

Istilah mubādalah sendiri ditujukan untuk menyebut sebuah relasi tertentu antara dua pihak yang mengandung nilai dan semangat kemitraan, kerja sama, kesalingan, timbal balik, dan resiprokal. Relasi yang dimaksud bisa terjadi di antara manusia secara umum, Negara

\footnotetext{
${ }^{10}$ Wawancara dengan Tia Isti'anah.

${ }^{11}$ Faqihuddin Abdul Kodir, Qira'ah Mubädalab: Tafsir Progresif untuk Keadilan Gender dalam Islam (Yogyakarta: IRCiSoD, 2019), 59.
} 
dan rakyat, majikan dan buruh, orang tua dan anak, guru dan murid, mayoritas dan minoritas. Ia juga meliputi relasi antara laki-laki dengan laki-laki atau antara perempuan dengan perempuan, antara individu atau antara masyarakat, dan bahkan komitmen manusia terhadap kelestarian lingkungan hidup, baik di skala lokal maupun global. ${ }^{12}$ Nampak bahwa Faqihuddin menggunakan konsep dan gagasan mubädalah ini dengan memproyeksikannya untuk pengembangan yang sangat luas melingkupi seluruh relasi yang mungkin terjadi dalam sebuah kehidupan manusia. ${ }^{13}$

Pada salah satu meme dijelaskan bagaimana gagasan tentang mubädalah ini bersinggungan dengan prinsip kebersamaan, kesetiakawanan, timbal balik (diibaratkan matahari yang selalu menyinari) dan prinsip kerjasama, kesederajatan, dan resiprositi (diibaratkan air yang selalu menyirami), dimana keduanya sangat berpengaruh dan menghasilkan kemaslahatan bagi seluruh makhluk (diibaratkan seperti bunga) sebagai target akhir yang hendak dituju. Beberapa pandangan yang dinilai sepihak dan problematis dihadapi oleh perempuan seperti: perempuan harus menjadi salihah, perempuan adalah aurat, sumber fitnah, kurang akal dan kurang agama, perempuan harus duduk di rumah serta tidak dianjurkan aktif di ranah publik dan bahkan dilarang menduduki posisi yang strategis. Jika pandangan seperti ini dilihat dalam perspektif gagasan mubadalah, maka kesemua hal yang awalnya ditujukan hanya untuk perempuan, bisa jadi berlaku pula untuk jenis kelamin laki-laki, bahwa laki-laki juga harus menjadi saleh, keduanya manusia yang mulia dan bermanfaat, dan bahkan soal aurat dan fitnah juga berpotensi muncul dari keduanya. Selain itu, keduanya mendapatkan amanah yang sama untuk saling menolong dan kerjasama dalam mengemban amanah dalam rumah tangga, ranah publik, dan menempati posisi strategis. ${ }^{14}$

\section{Hadis-Hadis Bermuatan Gender dalam Meme Akun Instagram @Mubadalah.Id}

Terdapat beragam topik yang sebenarnya diangkat dalam unggahan meme di akun@mubadalah.id. Akan tetapi tidak semua topik tersebut akan dibahas dalam penelitian ini. Berdasarkan fokus

\footnotetext{
12 Ibid., 59.

${ }^{13}$ Ibid., 60.

14 https://www.instagram.com/mubadalah.id/?hl=id, diakses pada 19 September 2020
} 
penelitian yang sudah disebutkan sebelumnya, topik yang diteliti dibatasi pada meme hadis yang secara eksplisit maupun implisit didasarkan pada hadis-hadis Nabi yang mengisyaratkan wacana kesetaraan gender. Sejumlah meme hadis yang menyiratkan pesan kesetaraan gender telah peneliti rangkum dalam tabel sebagai berikut,

\begin{tabular}{|c|c|c|c|}
\hline No & Judul Meme Hadis & $\begin{array}{l}\text { Tanggal } \\
\text { Unggahan }\end{array}$ & $\begin{array}{l}\text { Like } \\
\text { Comment }\end{array}$ \\
\hline 1 & Nabi Tentang Poligami & 9 Oktober 2017 & 26 likee \\
\hline 2 & $\begin{array}{l}\text { Kesadaran Atas Eksistensi } \\
\text { Perempuan Di Zaman Dulu }\end{array}$ & 18 Oktober 2017 & 8 like \\
\hline 3 & $\begin{array}{l}\text { Perempuan Tercipta Bukan } \\
\text { Dari Tulang Rusuk }\end{array}$ & 31 Juli 2018 & 18 like \\
\hline 4 & $\begin{array}{l}\text { Fitnah Dan Pesona Memang } \\
\text { Hanya Punya Perempuan } \\
\text { Doing Akhi }\end{array}$ & 22 Januari 2019 & $\begin{array}{l}278 \text { like, } 13 \\
\text { comment }\end{array}$ \\
\hline 5 & $\begin{array}{l}\text { Perempuan Hebat Pemberi } \\
\text { Nafkah Keluarga }\end{array}$ & 21 Februari 2019 & $\begin{array}{l}326 \text { like, } 11 \\
\text { comment }\end{array}$ \\
\hline 6 & $\begin{array}{l}\text { Ada Yang Masih Melecehkan } \\
\text { Perempuan }\end{array}$ & 6 Maret 2019 & $\begin{array}{l}268 \text { like, } 10 \\
\text { comment }\end{array}$ \\
\hline 7 & $\begin{array}{ll}\text { Islam Mengakui } & \text { Hak } \\
\text { Perempuan Lho } & \end{array}$ & 3 April 2019 & $\begin{array}{l}431 \quad \text { like, } 15 \\
\text { comment }\end{array}$ \\
\hline 8 & $\begin{array}{ll}\text { Larangan } & \text { Memukul } \\
\text { Perempuan } & \\
\end{array}$ & 25 April 2019 & $\begin{array}{l}170 \text { likee, } \\
\text { comment }\end{array}$ \\
\hline 9 & $\begin{array}{l}\text { Apakah Hanya Stri Yang } \\
\text { Harus Izin Suami }\end{array}$ & 3 Mei 2019 & $\begin{array}{l}258 \text { likee, } \\
\text { comment }\end{array}$ \\
\hline 10 & $\begin{array}{l}\text { Masa Iddah Perempuan Boleh } \\
\text { Kerja Kok }\end{array}$ & 6 Mei 2019 & $\begin{array}{l}118 \text { likee, } \\
\text { comment }\end{array}$ \\
\hline 11 & Haidmu Bukan Di Tanganmu & 12 Mei 2019 & $\begin{array}{l}1059 \text { like, } 38 \\
\text { comment }\end{array}$ \\
\hline 12 & $\begin{array}{l}\text { Perempuan Boleh Tidak Jadi } \\
\text { Imam }\end{array}$ & 21 Mei 2019 & $\begin{array}{l}508 \text { like, } 29 \\
\text { comment }\end{array}$ \\
\hline 13 & $\begin{array}{l}\text { Masih Beranggapan Bahwa } \\
\text { Perempuan Menjauhkan } \\
\text { Seseorang Dari Allah }\end{array}$ & 23 Mei 2019 & 150 like, \\
\hline 14 & Akutuu Manuia & 24 Mei 2019 & $\begin{array}{ll}298 & \text { like, } 5 \\
\text { comment } & \end{array}$ \\
\hline 15 & $\begin{array}{l}\text { Dilarang 'Azl Tanpa Izin Istri } \\
\text { Lho }\end{array}$ & 28 Mei 2019 & $\begin{array}{l}309 \text { like, } 16 \\
\text { comment }\end{array}$ \\
\hline 16 & $\begin{array}{l}\text { Kerja Domestik Tidak Ada } \\
\text { Kaitannya Dengan Jenis } \\
\text { Kelamin Ya }\end{array}$ & 2 Juni 2019 & $\begin{array}{l}401 \text { like, } \\
\text { comment }\end{array}$ \\
\hline
\end{tabular}




\begin{tabular}{|c|c|c|c|}
\hline 17 & $\begin{array}{l}\text { Bolehkah Perempuan } \\
\text { Menshalati Jenazah }\end{array}$ & 2 Juni 2019 & 97 like \\
\hline 18 & $\begin{array}{l}\text { Benarkah Perempuan Kurang } \\
\text { Akal \& Agama }\end{array}$ & 6 Juni 2019 & $\begin{array}{l}473 \text { like, } 18 \\
\text { comment }\end{array}$ \\
\hline 19 & $\begin{array}{l}\text { Nabi Mengapresiasi } \\
\text { Perempuan Pencari Nafkah }\end{array}$ & 8 Juni 2019 & $\begin{array}{l}543 \quad \text { like, } 9 \\
\text { comment }\end{array}$ \\
\hline 20 & $\begin{array}{l}\text { Membela Perempuan } \\
\text { Atu } \\
\text { Amanah Kenabian }\end{array}$ & 10 Juni 2019 & 282 like \\
\hline 21 & $\begin{array}{l}\text { Perempuan Juga Punya Hak } \\
\text { Minta Cerai Kok }\end{array}$ & 12 Juni 2019 & $\begin{array}{l}248 \text { like, } \\
\text { comment }\end{array}$ \\
\hline 22 & Hadis-Hadis Palsu Poligami & 14 Juni 2019 & $\begin{array}{l}854 \quad \text { like, } 24 \\
\text { comment }\end{array}$ \\
\hline 23 & $\begin{array}{l}\text { Nabi Tidak Rela Fatimah } \\
\text { Dipoligami }\end{array}$ & 15 Juni 2019 & $\begin{array}{l}831 \text { like, } \\
\text { comment }\end{array}$ \\
\hline 24 & $\begin{array}{l}\text { Perempuan Masa Nabi Itu } \\
\text { Aktif, Ekspresif, Dan Asertif }\end{array}$ & 18 Juni 2019 & $\begin{array}{l}475 \quad \text { like, } \\
\text { comment }\end{array}$ \\
\hline 25 & $\begin{array}{llr}\text { Mengapa } & \text { Sih } & \text { Karena } \\
\text { Perempuan } & \text { Lewat } & \text { Shalat } \\
\text { Seseorang (Bisa Jadi } & \text { Laki- } \\
\text { Laki) Menjadi Batal? } & \\
\end{array}$ & 23 Juni 2019 & 220 like \\
\hline 26 & Nabi Saja Melayani Keluarga & 26 Juni 2019 & $\begin{array}{l}195 \quad \text { like,1 } \\
\text { comment }\end{array}$ \\
\hline 27 & $\begin{array}{l}\text { Aqiqah Perempuan Dan Laki- } \\
\text { Laki 1:1 }\end{array}$ & 27 Juni 2019 & $\begin{array}{l}412 \quad \text { like, } 5 \\
\text { comment }\end{array}$ \\
\hline 28 & $\begin{array}{l}\text { Rasululah Tidak Mengkhitan } \\
\text { Putrinya }\end{array}$ & $\begin{array}{ll}19 & \text { September } \\
2019 & \\
\end{array}$ & $\begin{array}{l}606 \text { like, } \\
\text { comment }\end{array}$ \\
\hline 29 & $\begin{array}{l}\text { Hadis Palsu Yang Menistakan } \\
\text { Kemanusiaan Perempuan }\end{array}$ & $\begin{array}{ll}6 & \text { November } \\
2019 & \\
\end{array}$ & $\begin{array}{l}1204 \text { like, } 27 \\
\text { comment }\end{array}$ \\
\hline 30 & $\begin{array}{l}\text { Calon Suami } \text { Memukul } \\
\text { Putusin Aja }\end{array}$ & $\begin{array}{ll}7 & \text { November } \\
2019 & \\
\end{array}$ & $\begin{array}{l}428 \text { like, } \\
\text { comment }\end{array}$ \\
\hline 31 & Siti Aisyah Menggugat Hadis & $\begin{array}{ll}8 & \text { November } \\
2019 & \\
\end{array}$ & $\begin{array}{l}673 \quad \text { like, } 12 \\
\text { comment }\end{array}$ \\
\hline 32 & $\begin{array}{l}\text { Perempuan Berhak Memiliki } \\
\text { Senjata Untuk Mlindungi } \\
\text { Dirinya }\end{array}$ & $\begin{array}{ll}11 & \text { November } \\
2019 & \end{array}$ & $\begin{array}{l}2576 \text { like, } \\
\text { comment }\end{array}$ \\
\hline 33 & $\begin{array}{l}\text { Perempuan Dan Laki-Laki } \\
\text { Memilik Hak Pendidika Yang } \\
\text { Setara }\end{array}$ & $\begin{array}{ll}18 & \text { September } \\
2019 & \end{array}$ & $\begin{array}{l}828 \text { like, } \\
\text { comment }\end{array}$ \\
\hline 34 & $\begin{array}{l}\text { Dalam Islam, Ibu Adalah } \\
\text { Sumber \& Poros Kehdupan }\end{array}$ & 23 Dess 2019 & 217 like \\
\hline 35 & $\begin{array}{l}\text { Mengasuh Anak Perempuan } \\
\text { Perisai Dari Api Neraka }\end{array}$ & $\begin{array}{ll}25 & \text { Desember } \\
2019 & \\
\end{array}$ & $\begin{array}{l}265 \text { like, } \\
\text { comment }\end{array}$ \\
\hline
\end{tabular}




\begin{tabular}{|c|c|c|c|}
\hline 36 & Stop Mencibir Janda & 4 Januari 2020 & $\begin{array}{l}3806 \text { like, } 13 \\
\text { comment }\end{array}$ \\
\hline 37 & $\begin{array}{l}\text { Nabi Menolak Kekerasan } \\
\text { Terhadap Istri }\end{array}$ & 7 Januari 2020 & $\begin{array}{l}398 \text { like, } 3 \\
\text { comment }\end{array}$ \\
\hline 38 & $\begin{array}{lr}\text { Nabi } & \text { Muhammad } \\
\text { Membolehkan } & \text { Perempuan } \\
\text { Bekerja Pada Masa Iddah }\end{array}$ & 2 Maret 2019 & $\begin{array}{l}786 \quad \text { like,6 } \\
\text { comment }\end{array}$ \\
\hline 39 & Mengasuh Anak Tugas Siapa? & 15 Maret 2020 & $\begin{array}{l}490 \quad \text { like, } 3 \\
\text { comment }\end{array}$ \\
\hline 40 & $\begin{array}{lr}\text { Hadis-Hadis Tentang } & \text { Protes } \\
\text { Aisyah Kepada } & \text { Nabi } \\
\text { Muhamad Saw } & \end{array}$ & 11 April 2020 & $\begin{array}{l}1325 \text { like, } 33 \\
\text { comment }\end{array}$ \\
\hline 41 & $\begin{array}{l}\text { Dalil Perempuan Boleh } \\
\text { Menjadi Imam Shalat Tarawih }\end{array}$ & 4 Mei 2020 & $\begin{array}{l}1104 \text { like, } 242 \\
\text { comment }\end{array}$ \\
\hline 42 & $\begin{array}{l}\text { Mengasuh Anak Perempuan } \\
\text { Menghalangi Masuk Neraka }\end{array}$ & 11 Agustus 2020 & $\begin{array}{ll}525 & \text { like,1 } \\
\text { comment } & \\
\end{array}$ \\
\hline 43 & $\begin{array}{l}\text { Benarkah Perempuan Tercipta } \\
\text { Dari Tulang Rusuk Laki-Laki }\end{array}$ & 26 Agustus 2020 & $\begin{array}{l}1403 \quad \text { like, } 43 \\
\text { comment }\end{array}$ \\
\hline 44 & $\begin{array}{l}\text { Ummu Waraqah, Perempuan } \\
\text { Pertama Yang Menjadi Imam } \\
\text { Salat Bagi Laki-Laki }\end{array}$ & 25 Agustus 2020 & $\begin{array}{l}956 \text { like, } \\
\text { comment }\end{array}$ \\
\hline
\end{tabular}

Tabel 1: Meme Hadis di Akun@mubadalah.id

Berdasarkan tabel di atas, dapat dipahami bahwa tema-tema yang diangkat dalam postingan meme hadis dalam akun@mubadalah.id begitu beragam, yang semuanya memberikan perhatian besar pada pengakuan dan eksistensi perempuan baik di ranah domestik maupun publik, bahkan dalam ranah keagamaan. Data ini dikumpulkan dalam kurun waktu Agustus 2019 hingga tanggal September 2020. Jumlah pengguna yang menyukai dan komentar ditunjukkan guna mengetahui bagaimana respon yang dikemukakan oleh pengguna yang melihat unggahan ini.

Selanjutnya, peneliti membahas sejumlah meme dengan menggunakan analisis wacana dan mengulas dari perspektif kritik hadis. Adapun meme-meme hadis yang dielaborasi dibatasi pada tema berikut: pertama, counter atas stigmatisasi perempuan sebagai sumber fitnah, kurang akal dan kurang agama; kedua, konsep mahram bagi perempuan; dan ketiga, perempuan dalam pusaran pernikahan poligami. 


\section{Counter atas Stigmatisasi Perempuan Sebagai Sumber Fitnah, Kurang Akal dan Kurang Agama}

Tema ini direpresentasi oleh dua meme yang diunggah @ mubadalah.id pada tanggal 22 Januari 2019 dan 6 Juni 2019. Pertama-tama dibahas meme hadis yang mengkonter pandangan bahwa bukan hanya perempuan saja yang menjadi sumber fitnah.

\section{a. Laki-Laki juga Sumber Fitnah}

Meme ini diunggah pada tanggal 22 Januari 2019, disukai 277 akun, dan dikomentari oleh 13 akun. Isi meme ini menjadi menarik karena animasi yang digunakan menggunakan simbol identitas sebuah kelompok yang berjanggut dan menggunaan sapaan akhi-ukhti. Bentuk teks juga dibuat dalam bentuk dialog antara laki-laki dan perempuan di mana si laki-laki berkomentar:" Astaghfirullah, perempuan itu sumber fitnah, kok masih ada yang mau memamerkan auratnya, dia tidak tahu bahwa itu mengundang nafsu laki-laki”. Hal itu ditanggapi oleh si perempuan dengan menjelaskannya dalam perspektif psikologi bahwa hasrat biologis itu dimiliki baik oleh lakilaki maupun perempuan. Si laki-laki kemudian tidak menerima argumen tersebut karena menurutnya apa yang dikatakannya bersumber dari hadis Nabi. Barulah ketika si perempuan menimpali bahwa secara historis dalam kisah al-Qur'an dijelaskan bagaimana ketampanan Nabi Yusuf mampu membuat Siti Zulaikha tergoda, serta kisah ketampanan Sahabat Hajjāj b. Nashr yang juga membuat para perempuan kala itu tergoda. Pesan utama meme tersurat di bagian akhir dengan mengatakan bahwa bukan hanya perempuan yang menjadi sumber fitnah. ${ }^{15}$

Komentar yang muncul beragam, tetapi mayoritas saling men-tag temannya seakan ingin memberitahukan isi dari meme ini. Satu komentar menarik dari akun@lukas.bataya yang menanggapi akun @)muwashoffat: "sobat gurun mana mau dicerahkan dgn kayak gini". Lalu ia menimpali lagi, "jadi ga papa yaaa cewe selpi2”, dijawab oleh @adellart_@lukas.bataya "mereka selpi pke hp mereka sendiri, post diakun mereka sendiri, kok anda yg sewot, kyk sosial media haram utk cewe aja". Akun kin mien mengomentari dengan "berani ternyata ini

15 Mubadalah.id, "Laki-Laki juga Sumber Fitnah", https://www.instagram.com/p/Bs8CkNxn86c/. Diakses pada 19 september 2020. 
orang. Tetap tidak mengubah pemahaman saya, saya laki saya lebih tahu terfitnah oleh siapa." ${ }^{\prime 16}$

Meme ini secara eksplisit memang tidak mencantumkan hadis yang berkaitan dengan perempuan sebagai sumber fitnah. Hal ini bisa jadi karena pandangan ini dianggap sudah banyak diketahui secara luas oleh umat Islam. Di dunia maya sendiri wacana mengenai hal ini juga mengemuka antara pandangan "perempuan sumber fitnah sesuai dengan hadis" seperti dalam tulisan di website muslim.or.id" ${ }^{17}$, dan almanhaj.or.id ${ }^{18}$, ataukah "fitnah bisa muncul dari keduanya" seperti unggahan di islami.co ${ }^{19}$. Hadis yang seringkali dirujuk dalam hal ini adalah:
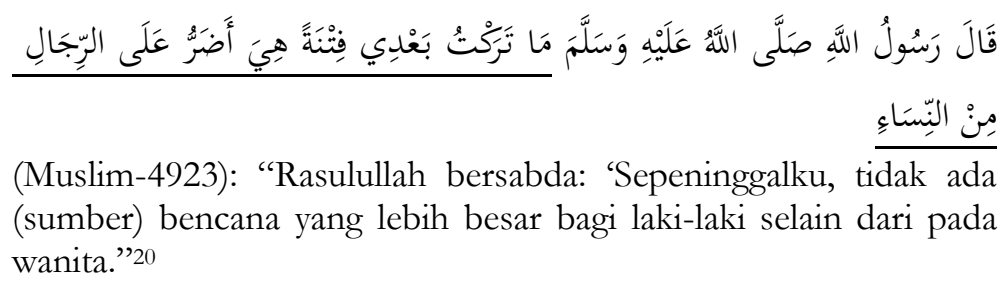

Secara kualitas, hadis ini bernilai sahih jika didasarkan pada penilaian kitab yang memuatnya, yakni Saḅ̆h Muslim. Selain itu sejumlah kitab hadis lain juga menyebutkan hadis ini dalam kitabnya, di antaranya Sahīh al-Bukbārì no.4706, Sunan al-Tirmidhì no.2704, Sunan Ibn Mäjah 3988, Musnad Aḅmad no.20751 dan 20828. ${ }^{21}$

16 Mubadalah.id, "Laki-Laki juga Sumber Fitnah", https://www.instagram.com/p/Bs8CkNxn86c/. Diakses pada 19 september 2020. 17 Agus Pranowo, "Wanita Ujian Terbesar Laki-Laki," dalam https://muslim.or.id/19526-wanita-ujian-terbesar-kaum-laki-laki.html. Diakses pada 26 September 2020.

18 Al-Ustad Yazid bin Abdul Qodir al-Jawas, "Waspadalah terhadap Fitnah Dunia dan Fitnah Wanita," dalam https://almanhaj.or.id/12733-waspadalah-terhadapfitnah-dunia-dan-fitnah-wanita-2.html. Diakses pada 26 September 2020.

19 Saifuddin Syadiri, "Memahami Hadis sebagai Sumber Fitnah, Apa Maksudnya," dalam https://islami.co/memahami-hadis-perempuan-sumber-fitnah-apamaksudnya/. Diakses pada 26 September 2020.

${ }^{20}$ Muslim, Shabih Muslim.pdf, Hadis No. 2741, Kitāb al-Raqāq, bāb Aktharu Abl alJannah al-Fuqarā' wa Aktharu Abl al-Nār al-Nisä' wa Bayān al-Fitnah bi al-Nisā', 1256. Muslim, Shabih Muslim, No. Hadis 4923, kitab dzikir, doa, taubat, dan istighfar, bab kebanyakan penduduk surga adalah orang-orang miskin, LIDW A Pusaka. Diakses pada 26 September 2020.

${ }^{21}$ LIDW A Pusaka. 


\section{b. Benarkah Perempuan Kurang Akal dan Agama?}

Salah satu meme yang mengandung stigmatisasi terhadap perempuan biasanya disarikan dari dalil agama (dari hadis) yang menyatakan bahwa perempuan itu kurang akal dan agama. Maka judul dari meme ini berupa pertanyaan, "Benarkah Perempuan Kurang Akal dan Agama?" Judul ini seakan-akan hendak meminta pembuktian atas asumsi ini. Meme ini dibuat dalam tiga slide: slide pertama berisi judul dan slide selanjutnya memuat pembahasan mengenai klarifikasi maksud hadis bahwa perempuan kurang akal dan agama. Admin mengutip pendapat Abū Shuqqah yang menilai bahwa hadis yang sudah banyak beredar di masyarakat tersebut sebenarnya adalah penggalan dari sebuah hadis yang panjang. Menurut Abū Shuqqah, hadis tersebut sebenarnya hendak memuji atau bergurau, karena memiliki lanjutan:

"saya kagum dengan para perempuan ini, (dianggap) hanya punya separuh akal dan agama, tetapi sangup mengalahkan laki-laki yang paling pintar dan teguh pendirian sekalipun".

Pada slide ketiga dijelaskan pula bahwa naqisāt al-aql bukanlah bermakna kurang akal, tetapi kurang berfikir. Lanjutan penjelasan selanjutnya:

"Kekurangan ini terjadi, karena struktur sosial tidak memberikan kesempatan kepada perempuan untuk belajar dan berlatih berfikir. Jika diberi kesempatan, maka perempuan akan dapat berfikir dengan baik, sebagaimana laki-laki. Laki-laki juga jika tidak diberi kesempatan berlatih dan belajar akan kurang kemampuannya dalam berfikir."

Begitu pula naqisät al-din juga bukanlah "kurang agama". Penjelasan selanjutnya bahwa:

"Ini hanya pernyataan simbolik perempuan kurang aktifitas puasa dan shalat ketika menstruasi, sebagaimana dijelaskan Nabi Muhammad. Meningalkan shalat dan puasa ketika menstruasi adalah perintah Allah. Sehingga mentaati perintah tersebut juga dalam rangka beribadah. Perempuan saat menstruasi dapat melakukan banyak hal untuk beribadah baik ritual/sosial."

Unggahan ini disukai oleh 478 akun dan telah dikomentari sebanyak 18 kali. Secara umum komentar menyatakan apresiasi, memuji, dan sikap setuju atas konten ini. Beberapa komentar dituliskan dengan menyinggung temannya dengan tanda arroba@. Bahkan akun@ah_udah menyatakan heran "Pemenggalan hadis 
semacam ini kok bisa terjadi? Senada dengan akun@miramelati29, "Kok bisa ada miskonsepsi seperti ini apalagi penggalan hadist ini sudah tersebar luas dan sering diucapkan oleh banyak pendakwah. So sad". Atas kegelisahan tersebut, akun@zeenoorputeri menanggapi bahwa hal tersebut terjadi karena penyakit orang-orang yang belajar agama secara instan. Lanjutnya, "al-Qur'an dan hadis itu rumit, harus liat sejarah dan konteksnya”. Akun@aurizzareads turut memuji dengan mengatakan bahwa akun ini lah yang ia cari, mampu memberikan dalil agama, non-jargonistik dan jelas. Begitu juga @ whatsupfadil yang menyatakan: "kesukaan terhadap akun ini, karena dinilai sangat mengedukasi secara detail tanpa adanya teriak-teriak". Nampaklah secara keseluruhan, komentar yang muncul sangat mendukung konten meme ini, tanpa ada sedikitpun yang menunjukkan sikap kontra.

Secara eksplisit penjelasan yang terdapat dalam meme hanya menuliskan penggalan hadis dari redaksi asli berikut,

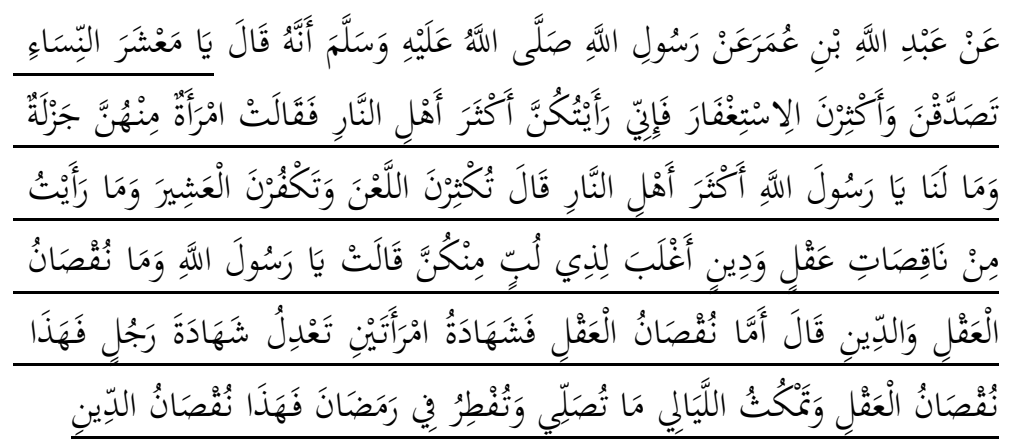

(Muslim-114): Dari 'Abdullāh b. 'Umar dari Rasulullah, bahwa beliau bersabda: "Wahai kaum wanita! Bersedekahlah kamu dan perbanyakkanlah istighfar. Karena, aku melihat kaum wanitalah yang paling banyak menjadi penghuni Neraka." Seorang wanita yang pintar di antara mereka bertanya, "Wahai Rasulullah, kenapa kaum wanita yang paling banyak menjadi penghuni Neraka?" Rasulullah bersabda: "Kalian banyak mengutuk dan mengingkari (pemberian nikmat dari) suami. Aku tidak melihat mereka yang kekurangan akal dan agama yang lebih menguasai pemilik akal, daripada golongan kamu." Wanita itu bertanya lagi, "Wahai Rasulullah! Apakah maksud kekurangan akal dan agama itu?" Rasulullah menjawab: "Maksud kekurangan akal ialah persaksian dua orang wanita sama dengan persaksian seorang lelaki. Inilah 
yang dikatakan kekurangan akal. Begitu juga kaum wanita tidak mengerjakan shalat pada malam-malam yang dilaluinya kemudian berbuka pada bulan Ramadlan (karena haid). Maka inilah yang dikatakan kekurangan agama." 22

Redaksi hadis di atas diriwayatkan dalam enam kitab hadis dengan jalur sanad yang berbeda-beda. Berdasarkan keseluruhan jalur sanad, ada 3 sahabat yang meriwayatkan hadis ini: Abū Hurayrah, 'Abdullāh b. 'Umar, dan Abū Sa'īd al-Khuḍīi. Secara kuantitas, sanad hadis ini bisa dikatakan sebagai hadis mustafid, berada dibawah tepat tingkatan hadis mutawatir. Begitupun secara kualitas, sanad hadis ini bisa dipastikan kesahihannya, karena diriwayatkan dalam kitab Șahị al-Bukhäri dan juga Sahīh Muslim yang dinilai sebagai kitab hadis yang paling sahih. Oleh karenanya, keberadaan hadis ini harus diterima sebagai fakta sejarah yang benar-benar terjadi pada masa $\mathrm{Nabi}^{23}$

Hanya saja, mengenai kandungan matan hadis yang ada di dalamnya, apakah termasuk ketetapan yang sampai bisa dikatakan kodrat perempuan, apalagi dikaitkan dengan predikat sebagai penduduk neraka yang paling banyak, masih perlu ditelaah lagi. Sejumlah peneliti telah melakukan upaya reinterpreasi terhadap kandungan matan hadis di atas, seperti yang dilakukan oleh Hamim Ilyas dan juga Faqihuddin Abdul Kodir. Hamim melihat bahwa konteks kemunculan hadis tersebut perlu dipertimbangkan, yakni ketika nabi hendak pergi ke masjid untuk shalat Id pada hari raya, yang kala itu di tengah perjalanan bertemu dengan kumpulan perempuan. Bisa jadi hadis nabi tersebut dituturkan sebagai nasehat untuk perempuan di zaman Nabi yang memiliki perilaku tertentu. Sehingga jika diperluas, nasehat tersebut bisa saja berlaku pada siapapun baik laki-laki maupun perempuan yang memiliki perilaku tidak terpuji. ${ }^{24}$

Hal ini pulalah yang menjadi telaah Faqihuddin dalam bukunya, Qira'ah Mubadalah. Peneliti mendapati bahwa teks dalam meme di atas sepertinya disarikan dari buku beliau. Beliau menegaskan bahwa hadis tersebut sesungguhnya sama sekali tidak menetapkan "akal dan agama

\footnotetext{
${ }^{22}$ Hadis Shabih Muslim, no. 114, dalam LIDW A Pusaka.

${ }^{23}$ Hamim Ilyas, "Kodrat Perempuan: Kurang Akal dan Kurang Agama" dalam Hamim Ilyas dkk., Perempuan Tertindas?: Kajian Hadis-Hadis Misoginis, ed. Mochamad Sodik dan Inayah Rohmaniyah (Yogyakarta, eLSaQ Press, cetakan ketiga 2008), 53 56.

${ }^{24}$ Ibid.
} 
perempuan yang bernilai separuh dari laki-laki," apalagi menetapkan superioritas laki-laki atas perempuan dalam segala hal, hanya karena seseorang itu berjenis kelamin laki-laki atau perempuan. Dengan menggunakan perspektif mubadalah, ia menyatakan bahwa hadis tentang perempuan kurang akal dan agama, yang bersifat parsial, ini harus dikembalikan kepada teks-teks yang lebih universal yang menjelaskan tentang kehormatan martabat perempuan sebagai manusia. Hal ini dilakukan agar pesan hadis di atas tidak dinilai bertentangan dengan Islam, serta agar menghasilkan pemaknaan yang proporsional. $^{25}$

\section{Konsep Mahram bagi Perempuan}

Meme ini berisi infografik yang membahas tentang konsep mahram. Meme dibuat dengan animasi gambar perempuan dan teks sebagai penjelasan atasnya. ${ }^{26}$ Meme ini menampilkan perbandingan konsep perlindungan zaman dahulu yakni mahram dan perlindungan zaman sekarang. Ilustrasi awal tentang konsep mahram zaman dahulu, bahwa dulu mahram yang berupa keluarga (saudara laki-laki, suami, maupun bapak) bertugas untuk memastikan keselamatan seseorang yang didampinginya. Sedangkan ilustrasi di bawahnya menceritakan bagaimana konsep perlindungan bukan lagi menjadi tanggung jawab mahram semata tetapi bisa juga menjadi tanggung jawab negara. Ilustrasi juga menggambarkan bagaimana realitanya saat ini menunjukan banyak perempuan yang beraktifitas secara mandiri di luar rumah, bahkan sampai berkuliah di luar kota dan juga luar negeri. Pesan penting meme yang ditunjukkan adalah bahwa agama tidak membatasi perempuan untuk berkarya. ${ }^{27}$

Postingan ini disukai oleh 140 akun, dan dikomentari oleh 8 akun yang mengomentari positif dan setuju dengan isi meme tersebut. Seperti akun@suciwid yang berkomentar :" Ini jawaban seng tak cari selama iniii "Konten ini diunggah 17 Januari 2019. Di bawah meme disebutkan bahwa penjelasan dalam konten ini dilansir dari artikel dengan judul "MAHRAM" adalah konsep perlindungan masa lalu". ${ }^{28}$

\footnotetext{
${ }^{25}$ Kodir, Qira'ah Mubadalah, 282.

26 Mubadalah.id, "Konsep Perlindungan Zaman Sekarang," dalam https://www.instagram.com/p/Bsu6NdMHY5F/. Diakses pada 19 September 2020.

27 Ibid.

${ }^{28}$ Ibid.
} 
Hadis tentang mahram memang secara eksplisit tidak dimunculkan dalam meme utama di atas. Akan tetapi kita bisa menelusuri teks hadis tersebut yakni dengan redaksi berikut:

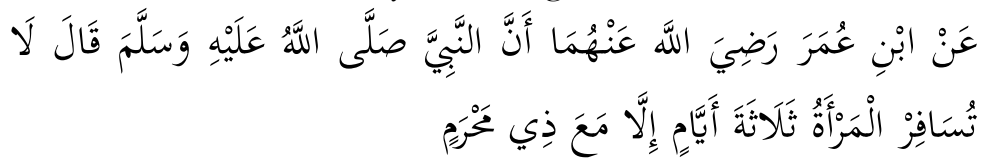

(Al-Bukhārī-1024): Dari Ibn 'Umar bahwa Nabi bersabda: "Seorang wanita tidak boleh mengadakan perjalanan diatas tiga hari kecuali bersama mahramnya." 29

Selain diriwayatkan oleh Imam Muslim dalam kitabnya, hadis ini juga termuat dalam sejumlah kitab hadis, seperti Șaḅị̧ al-Bukhārī, Musnad Ahmad, dan Sunan Ibn Mäjah dan lain sebagainya, dengan redaksi yang bervariasi melalui periwayatan sejumlah Sahabat seperti: Abū Hurayrah, 'Abdullāh b. 'Umar, dan Abū Sa'īd. Secara pragmatis,

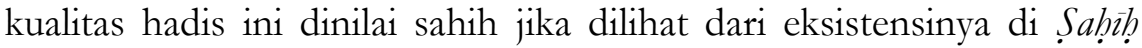
Muslim. Abdul Mustaqim dalam bukunya juga melakukan reevaluasi atas penilaian ini dan menemukan hasil yang sama, bahwa sanadnya muttasil (tersambung) dan para perawinya dinilai thiqqah semua, tidak ditemukan adanya shādh dan 'illah (cacat).

Secara pemaknaan hadis tersebut, Mustaqim kemudian melakukan rekonstruksi atas konsep mahram yang terdapat dalam redaksi hadis. Ia memberikan perhatian khusus pada konteks yang melatarbelakangi munculnya hadis tersebut. Meskipun tidak ada keterangan mengenai sabab al-wurüd hadis di atas, namun konteks kesejarahan masih bisa ditelusuri dengan menggunakan sabab al-wurūd al-ämmah dengan asumsi bahwa Nabi tidak mungkin berbicara dalam suatu kondisi masyarakat yang vakum. Ia sampai pada kesimpulan bahwa alasan Nabi melarang perempuan pergi sendirian kala itu adalah karena faktor keamanan dan keselamatan perempuan itu sendiri.

Terdapat sejumlah faktor yang melatarbelakangi, seperti halnya: medan geografis Arab yang bergurun, juga banyaknya tindak perampokan, juga ancaman binatang buas di tengah perjalanan. Selain

29 Al-Bukhārī, Sahīh al-Bukhārì, No.Hadis 1024, Kitab Jum'at Bab Berapa Jarak Perjalanan Yang Membolehkan Meng-Qashar Shalat, dalam LIDWA Pusaka ISoftware.

30 Abdul Mustaqim, Ilmu Ma'anil Hadits: Paradigma Interkoneksi (Yogyakarta: Idea Press, 2008), 155-165. 
itu, tradisi patriarki kiranya juga merupakan faktor pendukung yang kemudian semakin melegitimasi hadis tersebut sebagai ajaran Nabi yang harus dipatuhi tanpa melihat latar belakang kemunculannya. Maka untuk saat ini, manakala zaman sudah cukup banyak yang berubah, maka pemaknaan atas hadis di atas harusnya bisa lebih proporsional dengan mempertimbangkan realitas kehidupan yang telah banyak berubah. Untuk saat ini, konsep "mahram" yang awalnya bersifat personal sebenarnya bisa digantikan dengan sistem keamanan di bawah pemerintahan negara, yang dapat menjamin keselamatan dan keamanan perempuan tersebut. ${ }^{31}$

Jika kita melakukan pencarian di dunia maya, kita akan menemukan banyaknya diskursus tentang larangan bepergiannya perempuan tanpa mahram ini yang didasarkan pada hadis Nabi. Di Instagram misalnya, terdapat unggahan meme yang dibuat dengan teks terjemahan hadis beserta penjelasan maksud hadis secara tekstual. Bahkan beberapa meme dibuat dengan menggunakan ilustrasi animasi perempuan berpakaian gamis dan berjilbab besar. Maksud hadis pun kemudian diperluas sesuai dengan konteks yang dihadapi sekarang, misalnya saja dikaitkan dengan hukum muslimah berbocengan motor (naik ojek) dengan lelaki non mahram. ${ }^{32}$ Meski dikaitkan dengan realita kekinian, tetapi nalar yang mereka gunakan dalam memahami teks dan realita tersebut masih terpaku pada nalar bayani atas teks-teks hadis Nabi secara literal. Ada juga yang kemudian lebih tekstualis lagi dalam memahami konsep mahram, bahwa "berapapun jumlah perempuan yang menemanimu bepergian, ia tetaplah bukan mahrammu." ${ }^{33}$

\section{Perempuan dalam Pusaran Pernikahan Poligami}

Topik counter atas poligami di akun ini memiliki porsi kajian yang lumayan intens. Banyak meme yang dibuat dengan mengangkat tema ini. Secara bentuk isi meme, peneliti melihat ada ragam bentuk: pertama, dua meme berisi kutipan hadis dari Nabi; lima meme berisi pandangan poligami dari sejumlah tokoh; satu meme berisi

\footnotetext{
31 Ibid., 165-169.

32 Seperti meme yang diunggah akun@_ummu.qonitah di Instagram, 18 April 2020 dalam https://www.instagram.com/p/B_H9HAxBCIm/ diakses pada 28 September 2020.

${ }^{33}$ Ustadz Abu Salma Muhammad, "Hukum Safar Seorang Wanita Dengan Kawan Sesama Wanita," dalam https://www.fotodakwah.com/2019/01/hukum-safarseorang-wanita-dengan-kawan.html. Diakses pada 28 September 2020.
} 
pengalaman (berupa penyesalan) dari subjek poligami; satu meme menanggapi perceraian akibat poligami yang sedang viral; dan empat lainnya berisi penjelasan yang bersifat argumentatif, persuasif, bahkan nampak provokatif. Intensitas unggahan ini menurut hemat penulis menunjukkan perhatian besar@mubadalah.id terhadap isu ini.

Jika ditelusuri lebih jauh, isu poligami kembali menyeruak baik di dunia nyata maupun di dunia maya. Di dunia nyata banyak para perempuan korban poligami yang mulai membuka suara menceritakan pengalamannya. Begitu pula di dunia maya, mulai masif wacana atas kebolehan bahkan dinilai sebagai sunnah Nabi, bahkan ada yang berasumsi bisa menghilangkan kemiskinan. Sejumlah pihak ada yang kemudian sampai membuat pelatihan atau training agar bisa mendapat istri 4 dengan harga keikutsertaan yang lumayan mahal. ${ }^{34}$ Hal ini tentu saja menggugah para pegiat feminis Islam melakukan penolakan dengan keras. Mereka banyak menyuarakan pengalaman perempuan bahkan dari segi anak yang memiliki orang tua yang berpoligami. Hal inilah yang turut serta dilakukan oleh mubadalah.id di berbagai lini platform media sosialnya dengan lantang menyuarakan sunnah monogami sebagai bentuk counter atas wacana poligami tersebut.

\section{a. Narasi Hadis Penolakan Nabi terhadap Poligami}

Berdasarkan hasil penelaahan data awal, ada dua meme yang mengutip hadis, salah satunya diunggah pada unggahan pertama pada 9 Oktober 2017, dan yang kedua pada tanggal 15 Juni 2019. Keduanya sebenarnya mengutip redaksi yang sama, yakni hadis yang diriwayatkan oleh sahabat al-Miswar b. Makhramah dari Sahịh alBukbäri nomor hadis 5285.

Unggahan pertama pada 9 Oktober 2017, hanya mencantumkan terjemahan saja, sedangkan unggahan yang kedua menyertakan redaksi asli hadis dengan sanad sahabat saja berikut terjemahannya. Kala itu akun ini masih bernama@mubaadalah. Secara lay out, meme yang diunggah pertama dengan topik "NABI Tentang Poligami" hanya berisi terjemahan saja dengan sanad hanya mengutip nama sahabat.

\footnotetext{
${ }^{34}$ Dikutip dalam ABC, "Kelas Poligami di Indonesia Ajarkan Cara Kilat Dapat Empat Istri”, ABC Australia, 5 April 2019, https://www.tempo.co/abc/3953/kelaspoligami-di-indonesia-ajarkan-cara-kilat-dapat-empat-istri, diakses pada 24 November 2020.
} 
Postingan ini sendiri saat itu hanya di-like oleh 22 akun saja. ${ }^{35} \mathrm{Hal}$ ini bisa jadi karena saat itu akun ini masih dikatakan baru dan belum mendapatkan banyak pengikut. Hal ini berbeda dengan unggahan topik yang sama di waktu yang berbeda pada unggahan kedua.

Secara analisis teks, judul meme pada unggahan ini dibuat dengan penekanan pada kata 'NABI' yang ditulis dengan huruf kapital, berbeda dengan lazimnya judul yang dituliskan dengan kapital pada huruf awalnya saja, sebagaimana penulisan kata setelahnya. Dari sini, sepertinya pembuat meme hendak menonjolkan sosok Nabi, bahwa inilah sikap yang ditunjukkan oleh panutan utama umat Islam terhadap poligami.

Meskipun isi meme di unggahan pertama adalah hadis, namun yang disampaikan merupakan bentuk terjemahnya dalam bahasa Indonesia. Dalam terjemahan, biasanya terdapat pemilihan kata maupun istilah yang digunakan oleh penerjemah yang mana diksi tersebut sebenarnya mewakili ideologi dari si penerjemah. Apa yang dikutip oleh@mubadalah.id di atas merupakan terjemahan dari redaksi hadis berikut:

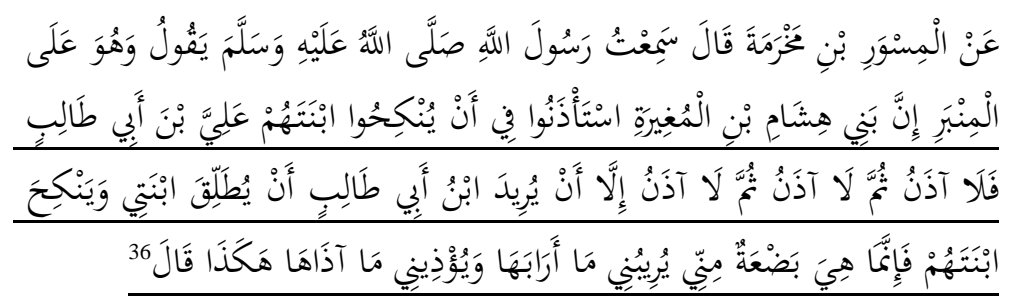

"Dari al-Miswar b. Makhramah ia berkata; saya mendengar Rasulullah berkutbah di mimbar: "Bani Hishām b. Mughīrah meminta izinku untuk menikahkan anak perempuan mereka dengan 'Alī b. Abī Tálib. Aku tidak mengizinkan, aku tidak mengizinkan, aku tidak mengizinkan, kecuali kalau 'Ali b. Abī Tālib menceraikan puteriku terlebih dahulu, lalu silahkan menikah dengan puteri mereka. Dia (putri saya Fatimah) adalah bagian dari diriku, sesuatu yang membuat hatinya galau akan membuat hatiku

35 Mubadalah, "Nabi Tentang Poligami," dalam https://www.instagram.com/p/BaBLhFlFezR/, diakses pada 15 November 2019. ${ }^{36}$ Abū 'Abd Allāh Muhammad b. Ismā'īl al-Bukhārī, Shahīh al-Bukhāri, vol. 3, nomor hadis 5230, Kitāb al-Nikeạh, bab zabb al-rajul 'an ibnatibi fi al-ghayrah wa al-inshafi (Libanon: Dār al-Kutub al-'Ilmīyah, 2009), 404-405. 
galau juga, dan sesuatu yang menyakitinya akan membuatku sakit juga." (H.R al-Bukhārī: 4829) ${ }^{37}$

Unggahan kedua mengenai topik ini diposting 1,5 tahun kemudian, 15 Juni 2019. Nampak respon dari follower cukup bagus jika dibandingkan dengan unggahan yang pertama. Tercatat terdapat 831 yang menyukai dan dikomentari sebanyak 42 komentar. Pada postingan meme hadis kedua, meme dibuat berbeda dari meme hadis yang pertama. Selain ditunjukkan redaksi asli hadis, dikutipkan pula sumber hadis (Șahīh al-Bukhäri, no. 5285), serta diperkuat dengan hasil takbrij hadis (sumber hadis lain yang juga memuat hadis ini), yaitu di Sunan Abū Dāwūd no 20731 dan Musnad Ahmad no. hadis 19229. ${ }^{38}$

Selain itu, admin akun juga memberikan tambahan deskripsi berikut.

"Jadi, dalam kasus poligami, perempuan yang tidak rela dan menolak poligami berarti ikut Fatimah dan termasuk "sunnah taqriri" karena disetujui Nabi. Laki-laki yang membela putrinya, saudarinya, atau temannya, agar tidak dipoligami adalah juga ikut nabi yang membela Fatimah dan berarti "sunnah. Begitu salinger. \#mubadalah \#poligami

Deskripsi tersebut sepertinya hendak memberikan kesimpulan, bagaimana memandang kasus poligami dalam konteks Hadis Nabi. Hal ini nampak manakala pada awal redaksi menggunakan kata 'jadi'. Logikanya, bisa dipahami sebagai berikut, pertama, dalam hadis Nabi tidak mengizinkan puterinya dipoligami, dan hal ini menunjukkan pembelaan Nabi atas Fatimah; kedua, perempuan yang tidak rela dan menolak poligami sebenarnya mengikuti Fatimah dan sunnah taqriri; ketiga, bisa dipahami secara lebih luas, siapa saja laki-laki yang menolak poligami terjadi pada putrinya, saudarinya, maupun temannya maka ia juga telah mengikuti sunnah Nabi.

\footnotetext{
37 Terjemahan hadis dalam meme di atas berbeda dengan terjemahan yang ada di software LIDWA Pusaka. Di aplikasi LIDWA terjemah dari kalimat fa là ädhana, thumma là ädhana, thumma là ädhana, hanya diterjemahkan namun akeu tidak mengizinkean kepada mereka.

38 Dalam khazanah Hadis, semakin banyak jalur sanad periwayatan sebuah hadis, maka akan dianggap semakin kuat secara kuantitas, bahkan juga menopang secara kualitas hadis. Keterangan takhrij dalam meme sepertinya hendak menunjukkan bahwa keberadaan hadis ini juga didukung redaksi lain dalam kitab-kitab hadis dalam tataran kutub al-tis'ah.
} 
Pada postingan ini komentar yang masuk cukup beragam. Ada yang merasa baru mengetahui jika ada hadis yang berbicara mengenai hal seperti ini. Akun@milana_kikiallen berkomentar: "Klo badistnya seperti ini kenapa jarang dibahas yaa..”, akun@rinni_ran juga berkomentar: "Hadist yg satu ini jarang banget dibabas ya". Ada pula yang kritis bertanya apakah sosok yang dimaksud perempuan dari Bani Hāshim b. al-Mughīrah adalah putri dari Abū Jahl sebagaimana yang disebutkan dalam kitab sirah (sejarah), karena jika demikian adanya menjadi sangat mungkin Rasulullah menolak dengan alasan tidak mungkin bersatu putri Rasulullah dengan putri musuh Allah.

Ada pula yang meragukan seperti akun@canned_chan_can dengan bertanya: "Ini sabih ga ya? Soalmya kata2nya bukan kata baku". Berdasarkan ragam komentar dan tanggapan tersebut, penulis melihat bahwa unggahan hadis akun@mubadalah.id mampu memberikan pencerahan sekaligus diskursus bagi netizen yang awam dengan matan hadis ini, bahkan membuat netizen yang kritis ingin lebih tahu tentang hal itu, sampai pada meragukan karena terjemahannya yang dianggap menggunakan bahasa kekinian.

\section{b. Meme Klarifikasi terhadap Hadis 'Palsu' Poligami}

Postingan meme memuat topik pokok 'Hadis Palsu Poligami' yang terdiri dari enam slide. Meme dibuat dengan model interaktif yang diawali dengan adanya curhatan seorang kawan dari Faqihuddin A. Kodir, mengenai sebuah hadis yang dijadikan dalil berpoligami oleh suami temannya yang ada di Nigeria.

Faqihuddin kemudian berusaha mencari sumber dari hadis tersebut melalui beberapa referensi yang ada, baik dalam kamuskamus hadis, software mawsü'at al-ḥadith al-sharif, software al-maktabah alshämilah, dan belum menemukan redaksi hadis tersebut secara persis, bahkan yang mirip sekalipun. Jalan terakhir yang ditempuh adalah pencarian cepat melalui perambah google. Dan memang didapati sejumlah website kajian hadis, seperti ahlalhadeeth.com dan sejumlah website berbahasa arab lainnya juga mengutip hadis ini. ${ }^{39}$

Pada kesimpulan akhirnya, menurut Faqihuddin, hadis tersebut adalah palsu, namun narasi ceritanya telah tersebar dalam dunia virtual, bahkan dunia nyata. Dalam satu pernyataannya dalam slide terakhir disebutkan bahwa "Karena palsu, maka penyebaran cerita

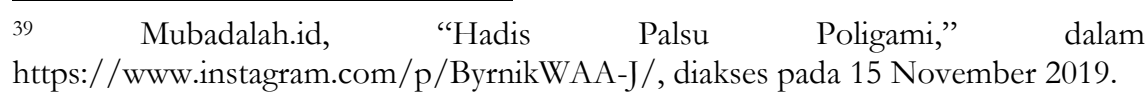


tersebut akan membenarkan tuduhan orang bahwa agama seringkali digunakan justru untuk mengeksploitasi perempuan secara fisik, psikis, sosial, bahkan ekonomi. Memalukan. Zalim. Dan karena itu haram."

Apa yang dilakukan oleh Faqihuddin dalam kajian hadis merupakan upaya kritik hadis atau naqd al-hadith dengan langkah awal melakukan penelusuran dengan metode takhrij al-hadith untuk memastikan eksistensinya, apakah memang benar-benar hadis atau bukan. Dan berdasar pencarian awal menggunakan berbagai aplikasi dan diskusi di kalangan pengkaji hadis, tidak bisa ditemukan. Oleh karenanya, tidak bisa dilanjutkan ke tahap selanjutnya, yakni kritik sanad dan kritik matan.

\section{Motif Dibalik Unggahan Meme Hadis Akun@Mubadalah.Id}

Peneliti melihat bahwa setidaknya ada dua motif yang melatarbelakangi unggahan meme hadis dalam akun mubadalah.id. pertama, meme hadis sebagai respon atas fenomena kekinian; kedua, meme hadis sebagai media sosialiasi dan publikasi gagasan mubadalah. Untuk uraian atas masing-masing aspek tersebut akan dielaborasi pada subbab di bawah ini:

\section{1) Meme Hadis sebagai Respon atas Fenomena Kekinian}

Meskipun gagasan mubadalah ini dicetuskan oleh Faqihuddin A. Kodir, akan tetapi konten meme hadis yang diunggah dalam akun ini murni merupakan inisiatif dari para pembuat konten meme. Mengenai topik yang dipilih, ada beberapa konteks yang melatarbelakangi. Adakalanya topik yang diangkat bertujuan untuk merespon fenomena yang tengah terjadi kala itu, seperti halnya meme tentang sunat perempuan dibuat dalam rangka merespon isu yang sedang hangat terjadi di masyarakat tertentu. Hal yang kemudian ia lakukan adalah mencari dalil-dalil dalam teks-teks keagamaan, buku-buku referensi mubadalah, atau buku jaringan ulama perempuan yang membahas tentang isu tersebut. ${ }^{41}$ Begitu pula dalam unggahan meme hadis terkait poligami juga bisa dikatakan terkait dengan fenomena yang tengah marak terjadi di masyarakat di dunia nyata, serta selalu menjadi topik perbincangan di dunia maya. Setiap ada fenomena tentang poligami

40 Mubadalah.id, "Hadis Palsu Poligami," dalam https://www.instagram.com/p/ByrnikWAA-J/, diakses pada 15 November 2019.

${ }^{41}$ Wawancara dengan Tia Isti'anah. 
menyeruak, maka pada saat itulah pro-kontra terhadap praktik ini timbul. $^{42}$

Pemberitaan yang juga sempat viral adalah adanya sebuah klub bernama Forum Poligami indonesia (FP Indonesia) yang aktif menggelar "cara kilat dapat istri empat" melalui serangkaian bimbingan dan pelatihan di berbagai kota. Untuk bisa mengikuti pelatihan ini, peserta diharuskan membayar biaya hingga 3,5 juta rupiah untuk kelas sehari penuh. Kelas poligami ini kemudian menjadi kontroversi di kalangan yang pro dan kontra. FP Indonesia tampaknya melihat peluang tersebut terutama di kalangan pria Muslim konservatif untuk mengikuti bimbingan dan persiapan kehidupan poligami. Sebagaimana hasil penelitian dari PPIM UIN Jakarta, bahwa media sosial saat ini tengah didominasi oleh pandangan muslim konservatif, terutama dalam topik-topik keperempuanan. ${ }^{43}$ Dalam hal ini pandangan mengenai kebolehan berpoligami sebagai bagian dari ajaran agama juga menjadi salah satu pandangan yang dianut oleh kelompok yang berpandangan konservatif ini.

Sebagaimana yang dikatakan Miski, bahwa realita dunia maya memiliki keterkaitan erat dengan realita yang terjadi di dunia nyata, meskipun masing-masing tetap memiliki karakteristiknya sendiri. ${ }^{44}$ Persoalan pernikahan dini, kekerasan terhadap perempuan, pelecehan seksual, dan juga poligami merupakan bentuk isu yang tengah hangat diberitakan di masyarakat. Hal ini dikarenanakan, secara realita hal itu memang dialami oleh para perempuan. Media sosial menjadi salah satu wadah yang kemudian digunakan para aktivis perempuan untuk menyuarakan persoalan-persoalan kemanusian perempuan tersebut. Dan terbukti bahwa hal tersebut mampu menggugah kesadaran masyarakat luas, terutama para kaum muda-mudinya untuk turut concern menyuarakan dan mengadvokasi solusi atas persoalan tersebut kepada pemerintah.

Hadis sendiri memiliki keterkaitan yang erat dengan media sosial. Hal ini bisa dilihat dari kesesuaian antara karakteristik keduanya yaitu

42 Zia El-Muttaqin, Susilatuti DN, Christina Rochayanti, "Pemberitaan Mengenai Poligami di Surat Kabar Nasional (Analisis Framing terhadap Pemberitaan Poligami di Surat Kabar Harian Nasional Seputar Indonesia Edisi Desember 2006-Januari 2007), Jurnal Ilmu Komunikasi, Vol. 6, No. 3 (2008), 191.

43 Iim Halimatussa'diyah, Beragama di Dunia Maya: Media Sosial dan Pandangan Keagamaan d Indonesia (Jakarta: PPIM UIN Jakarta, 2020), iii-iv.

${ }_{44}$ Miski Mudin, Islam Virtual: Diskursus Hadis, Otoritas, dan Dinamika Keberislaman di Media Sosial, ed. Nurul Afifah (Yogyakarta: BILDUNG, 2019),68. 
sama-sama berkarakter penyampaian singkat, padat, dan sarat makna. Selain itu hadis sebagai ajaran Nabi banyak diminati oleh umat Muslim yang aktif di sosial media sebagai materi dakwah yang mengajak orang lain menuju kebaikan. Meskipun adakalanya dibalik pesan dakwah tersebut ada celah yang mereka gunakan untuk mengenalkan kepentingan ideologi mereka. ${ }^{45}$ Maka, publikasi meme hadis dalam akun@mubadalah.id sepertinya juga tidak terlepas dari bingkai relevansi ini. Tia mengakui bahwa ia juga banyak terpengaruh atas isu yang sedang terjadi saat itu. Hal ini tentu saja sangat berkaitan pula dengan perhatiannya terhadap isu-isu ketidakadilan juga jaringan komunikasinya dengan gerakan feminism lainnya baik di dunia nyata maupun maya.

\section{2) Meme Hadis Sebagai Media Sosialiasi dan Publikasi Gagasan Mubadalah}

Selain motif yang telah disebutkan di atas, adakalanya juga topik yang dibuat konten diinisiasi oleh pembuat konten itu sendiri. Hal yang demikian bertujuan untuk membuat alternatif isu manakala topik yang diangkat adalah sesuatu yang selalu relevan kapanpun dan dimanapun serta selalu diperbincangkan. ${ }^{46}$ Seperti halnya salah satu topik yang dikaji dalam penelitian ini, yakni counter atas stigmatisasi perempuan sebagai sumber fitnah, kurang akal dan agama. Memang tidak bisa dipungkiri, pelabelan atau stereotype seperti ini sudah merajalela dalam pandangan masyarakat kita yang patriarkal. Stereotype tentang perempun sumber fitnah, kurang akal dan agama yang berasal dari dalil agama ini pada akhirnya berpotensi melahirkan subordinasi terhadap perempuan, disamping juga marginalisasi, bahkan menimbulkan kekerasan dalam relasi gender. ${ }^{47}$

Hal ini bisa nampak dari komentar yang muncul dalam postingan ini. Dalam unggahan meme perempuan sebagai sumber fitnah, akun

\footnotetext{
${ }^{45}$ Ibid., 86-88.

46 Wawancara dengan Tia Isti'anah

${ }^{47}$ Hal ini bisa dikatakan sebagai manifestasi dari ketidakadilan gender, sebagaimana dituliskan Mansour Fakih dalam bukunya. Ia memerinci bentuk ketidakdilan gender yang dialami oleh perempuan selama ini yang mencakup: marginalisasi (proses pemiskinan ekonomi), subordinasi (anggapan tidak penting), stereotype (pelabelan negatif), beban ganda (beban kerja lebih panjang dan lebih banyak), violence (kekerasan), dan sosialisasi ideologi nilai peran gender. Baca selanjutnya Mansour Fakih, Analisis Gender dan Transformasi Sosial (Yogyakarta: Pustaka Pelajar, cetakan keenam, 2001), 12.
} 
@ kin_mien mengomentari kontra dengan "berani ternyata ini orang. Tetap tidak mengubah pemahaman saya, saya laki saya lebih tahu terfitnah oleh siapa." Tanggapan seperti ini, menurut hemat penulis, menunjukkan bagaimana pandangan perempuan sebagai sumber fitnah sudah tertancap dalam tingkat kesadaran yang paling dalam yang kemudian bisa saja dianggap sebagai sebuah pandangan yang benar. Terhadap perdebatan pro-kontra di laman komentar unggahan ini, tidak banyak direspon oleh admin akun tersebut. Meskipun sebenarnya netizen yang berkomentar lebih banyak yang menilai positif atas konten ini.

Persoalan kesetaraan gender perspektif Islam sebenarnya sudah banyak dikaji dan ditulis dalam banyak buku penting. Hal itulah yang menurut Tia menjadi kelebihan tersendiri, karena sumber bacaan yang sebenarnya melimpah dan mudah diakses. Berdasarkan referensi tersebut, Tia kemudian meresume tulisan yang ada, dan kemudian memilih topik alternatif yang perlu publik ketahui, ataupun mencari tahu apa yang sedang tersebar di publik. Prinsip yang harus dipegangi dalam pembuatan meme adalah konten yang disajikan tidak boleh merugikan perempuan maupun laki-laki. Hal ini sesuai dengan prinsip gagasan mubadalah yang menonjolkan prinsip kesalingan dalam sebuah relasi. Dalil yang dicari pun tidak boleh merugikan perempuan. Menurut Tia, perempuan seringkali dirugikan atas pemahaman teks teks agama yang sedang berkembang. ${ }^{48}$

Perhatiannya terhadap isu yang hendak dimuncullkan oleh Tia selaku content creator tentunya tidak lepas dari pengaruh pengalamannya sebagai sosok muda yang dekat dengan media sosial, juga keaktifannya dalam organisasi mubadalah. Sebagaimana kita tahu, dalam beberapa event kegiatan maupun kutipan teks dalam meme serta tulisan yang ditampilkan di website nya banyak mengusung pemikiran tokohtokoh seperti Kiai Husen Muhammad, Faqihuddin A. Kodir, Bu Nyai Badriyah Fayumi, Nur Rofi'ah, Ruby Kholifah, Alissa Wahid, dan tokoh-tokoh lainnya. Tokoh-tokoh tersebut dikenal sebagai tokoh feminis Muslim Indonesia ${ }^{49}$ yang juga banyak bergerak dalam isu-isu kemanusiaan. ${ }^{50}$ Maka peneliti melihat bahwa content creator dan admin dalam akun ini juga menjadi perpanjangan ideologi para tokoh feminis

\footnotetext{
48 Wawancara dengan Tia Isti'anah.

49 Muslim Feminis di sini adalah mereka baik laki-laki maupun perempuan yang mendukung wacana dan gerakan kesetaraan gender.

${ }^{50}$ Moh. Asror Yusuf, Wacana Kesetaraan Gender di Indonesia: Antara Muslim Feminis dan Revivalis (Kediri: STAIN Kediri Press, 2010), 72-75.
} 
muslim yang pemikiran mereka, baik tertulis maupun tidak, menjadi rujukan penting bagi para content creator muda mubadalah.id, khususnya gagasan mubadalah yang diinisiasi oleh Faqihuddin Abdul Kodir.

Selama ini gagasan mengenai kesetaraan gender yang diusung oleh feminis banyak mengalami kendala. Mulai dari istilah gender dan feminis yang dinilai bukan merupakan bagian dari ajaran Islam, tapi malah berasal dari Barat menjadi salah satu alasan penolakan terhadap wacana ini. Selain itu muncul miskonsepsi atau kesalahpahaman terhadap konsep ini menambah sulitnya penerimaan wacana ini di kalangan Muslim Indonesia. Terlebih dominasi tradisi patriarkal yang telah lama mengakar juga menjadi penyebab sulitnya penerimaan atas sesuatu yang bertentangan dengannya. Gagasan mubadalah sendiri sebenarnya memiliki pandangan yang lebih bisa diterima, karena gagasannya mendasarkan pada dalil-dalil agama, baik al-Qur'an maupun Hadis. Apalagi yang diperjuangkan bukan semata-mata kepentingan perempuan semata, melainkan juga kemaslahatan semua manusia, termasuk laki-laki, baik dalam relasi rumahtangga, maupun keluarga, bahkan negara.

Upaya Tia dengan meme hadisnya kemudian terbukti banyak diterima oleh berbagai pihak. Selama ini, perbincangan mengenai perlunya mereinterpretasi wacana teks keagamaan yang dinilai menimbulkan stigma negatif terhadap perempuan memang sudah lama menarik minat para penggiat gender Islam. ${ }^{51}$ Akan tetapi wacana tersebut disampaikan dalam bentuk tulisan panjang dan eksklusif diperbincangkan dalam kelas maupun diskusi akademis. Penerimaan isu-isu gender di kalangan millennial, terutama netizen masih mengalami kendala karena berbagai faktor hal. Kehadiran meme hadis yang mengusung counter atas isu stigmatisasi perempuan, juga konsep mahram bagi perempuan merupakan bentuk publikasi atas informasi akan pentingnya merubah pandangan yang selama ini keliru terhadap diri perempuan.

\section{Kesimpulan}

Secara umum bentuk-bentuk wacana kesetaraan gender yang diusung oleh akun mubadalah.id dalam bentuk meme hadis meliputi sejumlah tema besar yang begitu beragam, yang semuanya memberikan perhatian besar pada pengakuan dan eksistensi perempuan baik di ranah domestik maupun publik, bahkan dalam

${ }^{51}$ Ibid., 72-75. 
ranah keagamaan. Dalam penelitian ini, peneliti hanya memberikan fokus atas studi kasus beberapa meme yang diklasifikasikan kedalam tiga tema besar, yakni pertama, counter atas stigmatisasi perempuan sebagai sumber fitnah, serta kurang akal dan agama; kedua, konsep mahram bagi perempuan; dan ketiga, perempuan dalam pusaran pernikahan poligami.

Peneliti melihat bahwa setidaknya ada dua motif yang melatarbelakangi unggahan meme hadis dalam akun mubadalah.id. pertama, meme hadis sebagai respon atas fenomena kekinian; kedua, meme hadis sebagai media sosialiasi dan publikasi gagasan mubadalah. Di satu sisi, meme hadis merupakan hasil ide kreatif dan tidak terlepas dari pengalaman si pembuat meme. Pada sisi yang lain, terdapat pemikiran tokoh-tokoh feminism Islam yang turut menjadi rujukan si pembuat meme.

\section{DAFTAR PUSTAKA}

Bukhārī (al), Abū 'Abd Allāh Muḥammad b. Ismāồil. Ṣahīh al-Bukhārì. Libanon: Dār al-Kutub al-'Ilmìyah, 2009.

El-Muttaqin, Zia, Susilatuti DN, dan Christina Rochayanti. "Pemberitaan Mengenai Poligami di Surat Kabar Nasional (Analisis Framing terhadap Pemberitaan Poligami di Surat Kabar Harian Nasional Seputar Indonesia Edisi Desember 2006-Januari 2007)." Jurnal Ilmu Komunikasi, Vol. 6, No. 3 (2008).

Fakih, Mansour. Analisis Gender dan Transformasi Sosial. Yogyakarta: Pustaka Pelajar, 2001.

Halimatussa'diyah, Iim. Beragama di Dunia Maya: Media Sosial dan Pandangan Keagamaan d Indonesia. Jakarta: PPIM UIN Jakarta, 2020.

Ilyas, Hamim. "Kodrat Perempuan: Kurang Akal dan Kurang Agama," dalam Hamim Ilyas, dkk. Perempuan Tertindas? Kajian Hadis-Hadis Misoginis. Diedit oleh Mochamad Sodik dan Inayah Rohmaniyah. Yogyakarta: Elsaq Press dan PSW, 2008.

Kodir, Faqihuddin Abdul. Qira'äh Mubädalab: Tafsir Progresif untuk Keadilan Gender dalam Islam. Yogyakarta: Diva Press, 2019.

Mahmudah, Rifatul, dan Imron Gozali. "Pesan Ramah dalam Meme Akun Instagram Jaringan Gusdurian dan Fihril (Kajian Pragmatik)." Jurnal Estetik, Vol.1 No.2, (2018). 
Mudin, Miski. "Fenomena "Meme" Hadis Celana Cingkrang dalam Media Sosial." Jurnal Harmoni: Jurnal Multikultural dan Multireligius, Vol.16, No.2, (2017).

- Islam Virtual: Diskursus Hadis, Otoritas, dan Dinamika Keberislaman di Media Sosial. Yogyakarta: CV Bildung, 2019.

Mustaqim, Abdul. Ilmu Ma'anil Hadis. Diedit oleh Habib. Yogyakarta Idea Press, 2008.

Nasrullah, Rulli. Teori dan Riset Media Siber (Cybermedia). Jakarta: Prenadamedia. 2014.

Nugraha, Aditya. "Fenomena Meme di Media Sosial: Studi Etnografi Virtual Posting Meme Pada Pengguna Media Sosial Instagram." Jurnal Sosioteknologi, Vol. 14, No. 3 (2015).

Pratama, Bayu Indra. Etnografi Dunia Maya Internet. Malang: UB Press, 2017.

Rifani, Aurora Nurhidayah. "Media Sosial dan Aktivisme: Medium Pemaknaan Ulang Narasi Islam oleh Akun Instagram @mubadalah.id,@muslimahfeminis,dan@cherbonfeminist." Tesis, Universitas Indonesia, 2020.

Software LIDWA Pusaka i-Software- Kitab 9 Imam Hadist.

Syahridawati dan Saifuddin Zuhri. "Contestation of Hadith Memes on the Prohibition of Music." Journal of Hadith Studies, Vol. 2, No. 1 (2019).

Umar, Nasaruddin. Argumen Kesetaraan Gender Perspektif al-Qur'an. Jakarta: Penerbit Dian Rakyat, cetakan ke-II, 2010.

Wawancara dengan Tia Isti'anah

Yusuf, Moh. Asror. Wacana Kesetaraan Gender di Indonesia : Antara Muslim Feminis dan Revivalis. Kediri: STAIN Kediri Press, 2010.

\section{Sumber Internet}

ummu.qonitah. https://www.instagram.com/p/B_H9HAxBCIm/, diakses pada 28 Septemeber 2020.

ABC. "Kelas Poligami di Indonesia Ajarkan "Cara Kilat Dapat Empat Istri”. ABC Autralia. 5 April 2019. https://www.tempo.co/abc/3953/kelas-poligami-di-indonesiaajarkan-cara-kilat-dapat-empat-istri, diakses pada 24 November 2020.

fahd_hasan24. "Silahkan tinggalkan poligami bagi yang tak mampu, silahkan berlaku adil bagi yang bisa". Instagram. 
https://www.instagram.com/p/ByJ5gxqnjmt/igshid=1kr0yp5r rdzca, diakses 11 Agustus 2019.

Jawas (al-), Al-Ustad Yazid bin Abdul Qodir. "Waspadalah terhadap Fitnah Dunia dan Fitnah Wanita," dalam https://almanhaj.or.id/12733-waspadalah-terhadap-fitnahdunia-dan-fitnah-wanita-2.html. Diakses pada 26 September 2020.

Mubaadalah, "Nabi Saw 'tidak rela' Fatimah (Putri Baginda) Dipoligami”, Instagram, 15 Juni 2019, diakses 12 Agustus 2019, https://www.instagram.com/p/ByuvwkJAAhw/.

Mubadalah.id, "Hadis Palsu Poligami", Instagram, https://www.instagram.com/p/ByrnikWAA-J/. Diakses pada 12 Agustus 2019.

Mubadalah.id, "Laki-Laki juga Sumber Fitnah", https://www.instagram.com/p/Bs8CkNxn86c/. Diakses pada 19 September 2020.

Mubadalah.id. "Konsep Perlindungan Zaman Sekarang”. https://www.instagram.com/p/Bsu6NdMHY5F/. Diakses pada 19 September 2020.

Mubadalah.id."Nabi Tentang Poligami". Instagram. https://www.instagram.com/p/BaBLhFlFezR/, diakses pada 15 November 2019.

Pranowo, Agus. "Wanita Ujian Terbesar Laki-Laki," dalam https://muslim.or.id/19526-wanita-ujian-terbesar-kaum-lakilaki.html. Diakses pada 26 September 2020.

Syadiri, Saifuddin. "Memahami Hadis sebagai Sumber Fitnah, Apa Maksudnya," dalam https://islami.co/memahami-hadisperempuan-sumber-fitnah-apa-maksudnya/. Diakses pada 26 September 2020.

Muhammad, Abu Salma. "Hukum Safar Seorang Wanita Dengan Kawan Sesama Wanita," dalam https://www.fotodakwah.com/2019/01/hukum-safar-seorangwanita-dengan-kawan.html. Diakses pada 28 September 2020. 